\title{
重味付残差法による臨海域帯水層内の塩水僈入解析
}

\section{Numerical Analysis of Salt-Water Intrusion in Coastal Aquifer by Weighted Residuals Method}

藤 间 聡 $*$

\author{
Satoshi Toнma *
}

\begin{abstract}
A weighted residuals method based on Galerkin's finite element technique is applied to investigate the salt-water intrusion and dispersion in the coastal aquifer. The salt-water intrusion phenomenon was treated as the density-dependent flow of two immiscible and miscible fluids.

The mathematical formulation of miscible density-dependent flow consists of the coupled form of the flow equation and the convective diffusion equation.

The present analysis uses two dimensional quadrilateral, isoparametric elements with a linear basis function for piezometric head, salt concentration and velocity components.

From the comparison of the numerical results with the experimental results, this procedure can handle the salt-water intrusion in the coastal aquifer.
\end{abstract}

* 室荿工業大学土木工学科 * Department of Civil Engineering Muroran Institute of Technology 


\section{1 緒 論}

臨海域帯水層における塩水侵入に関する研究は，Ghyben・Herzberg の静的平衡論に始まり，現 在に至るまで多数の研究者により，侵入現象の水理特性の解明及び解析手法の開発がなされてきた。

塩水侵入の解析は, 塩分の分散を無視した非混合密度流理論に基つくるのと, 分散を考虑に入れた 混合密度流理論に基づくものとに大別することができる。

前者は塩・淡水域間に存在する払散帯を明瞭な境界面で近似し，塩水侵入を移動境界問題として取 扱い，塩・淡水境界面形状及び位置を決定する手法である。既往の解析の大部分はこれに属し，淡水 の流れの状態を準一様流理論によって定式化し，これを解析的に解くことにより塩水侵入の解明を行 っている。この解析法は簡便性があり，比較的精度良く現象を説明し得るが，塩分の分散が顕著な場 合や鉛直流速が卓越する海岸線付近及び揚水井の周辺に扣いては，精度が著しく低下寸る。

一方, 後者の混合密度流理論に基づく解析法は, 塩分輸送量及び濃度の予測に用いられる。塩分の 分散機構は非常に複雑で, 塩分濃度は地下水の流動に影響を与えると同時に，この流動は塩分の分散 に影響を与える。このため地下水は不均質流体となり，解析的な解を求めることが困難となる。

本研究は, 重味付残差法を用いて塩水侵入の解析を行ら。非混合密度流に関しては, 準一様流が成 立しない場合も含めて，塩・淡水境界面形状及び淡水流出量の推定を行い，Hele-Shaw モデルの実 験結果により検証する。混合密度流に関しては, 地下水の流速と塩分濃度を連成させて塩分の移動と 濃度分布を予測する数値解析手法を提案し，その適用性を確めるるのである。

\section{2 基礎式}

\section{2-1 非混合塩淡水密度流}

潮汐に起因する塩水の往復運動が微小である帯水層に括いては, 塩・淡水の混合の結果生ずる拡散 帯は帯水層厚に比較して相対的に狭小である。このため境界面は明瞭な曲線で近似でさる。

この状態に和ける河口湖堤体内の塩水侵入を Fig-1に示す。

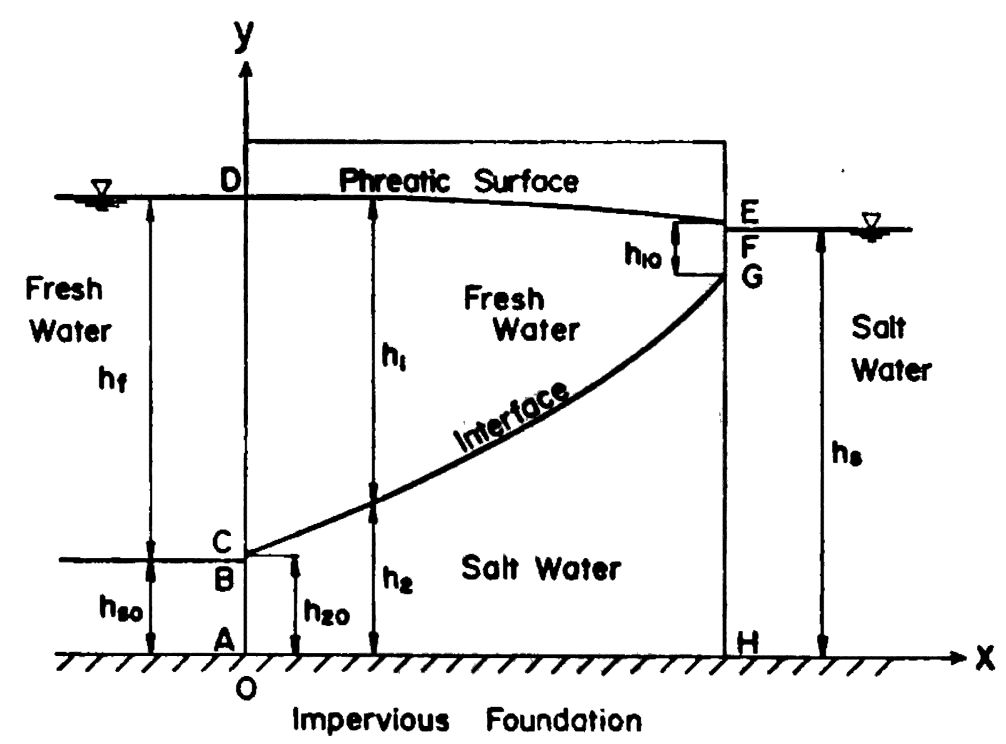

Fig-1 Definition Sketch of Salt-Water Intrusion in Coastal Aquifer System.

同図に打いて，堤体の左方水域を淡水 域，右方水域を塩水域とし，堤体内では漫 透流は自由水面を有する。また罒中の記号 は，それぞれ次の水理量を表わす。 $h_{f}$ : 淡水域に扣ける淡水深。 $h_{10}$ :塩水域へ流出する㳄水深, $h_{20}$ : 淡水域へ流出する塩水深, $h_{1}$ : 堤体内に和ける淡水深, $h_{2}$ : 堤体内における塩水深, hs : 塩水域における塩水深, $h s_{0}$ : 淡水域に扣ける塩水深。

非混合塩淡水密度流の基礎方程式を尃び くにあたり，本解析では，次の仮定を設け る。 
(a) 堤体内の密度流は，二次元流れで Darcy 則に従う。

(b) 塩・淡水境界面上での毛管圧は無視する。

（c）各流体は均質非圧縮性とする。

(d) 温度勾配は無視する。

（e）堤体は均質多孔媒体とし，水平不浸透基礎地盤上にある。

以上の仮定を用いて，塩・淡水内部境界面に関して，定常及び非定常解析を行ら。

\section{（1）非定常解析}

\section{(i) 支配方程式}

不压浸透流に関する連続の式は，前述の仮定に基づき次式で定義される。

$$
\begin{aligned}
& \frac{\partial}{\partial x}\left(K_{x i} \frac{\partial H_{i}}{\partial x}\right)+\frac{\partial}{\partial y}\left(K_{y i} \frac{\partial H_{i}}{\partial y}\right)=q_{0 i}+S \frac{\partial H_{i}}{\partial t} \\
& H_{i}=\frac{p_{i}}{\rho_{i} g}+y, \quad K_{x i}=\frac{k_{x} \gamma_{i}}{\mu_{i}}, \quad K_{y i}=\frac{k_{i} \gamma_{i}}{\mu_{i}}, \quad i=1 \text { or } 2
\end{aligned}
$$

上式中, 添字は, $i=1$ が淡水, $i=2$ が塩水の諸元を示し, 座標系は $x$ が水平方向を, $y$ は鉛直 方向をそれぞれ示す。

$H$ : 水頭, $K_{x}$ : 水平方向の透水係数, $K_{y}$ : 鉛直方向の透水係数, $q_{o}$ : 単位時間, 単位面積当りの 揚水量又は涵養量, $S$ : 比詝留量, $\rho$ : 密度, $\mu$ : 粘性係数, $\gamma$ : 流体単位重量, $k$ : 固有透過度であ る。

\section{（ii）塩・淡水境界面及び自由水面境界条件}

塩・淡水境界及び自由水面は異種の流体間の接触面である。

いま，境界面形状を(2)式で表わす。

$$
\mathbf{F}(x, y, t)=y-h_{2}(x, t)=0
$$

こ〉で， $h_{2}$ は不浸透基礎地盤から塩・淡水境界面まで鉛直距離を表わす。

(2)式に拈いて $F(x, y, t)=0$ を保ちながら $t$ の值を変化させると, 種々の表面が得られる。こ れらの表面はもとの表面が時間とともに移動した結果できた表面と考え，また，この面は常に同一流 質により構成される物質面であると仮定すると次式が満足される。

$$
\frac{D F}{D t}=\frac{\partial F}{\partial t}+(V \cdot \nabla F)=\frac{\partial F}{\partial t}+\frac{1}{n_{e}}(\mathbf{q} \cdot \nabla F)=0
$$

上式中， V は流体の実流速， $n_{e}$ は有効空吵率， q は Darcy 法則により得られる浸透流速で V と の関係は次式で与えられる。

$$
\mathbf{q}=n_{e} \mathbf{V}
$$

(3)式における $F$ の解を求めるためには，あらかじめ $\mathbf{V}$ が既知でなければならない。従って堤体内 に㧍ける水頭分布を先に決定するか， $F$ と連成させて解くことになる。

塩・淡水境界面上で毛管圧を無視すると，この面では圧力が連続しなければならないことから境界 面の位置は次式で与えられる。 


$$
h_{2}=\frac{\rho_{2} H_{2}-\rho_{1} H_{1}}{\Delta \rho}
$$

ただし， $\Delta \rho=\rho_{2}-\rho_{1}$

(5)式を(2)式に代入し $h_{2}$ を消去した後，(3)式に代入すると，次の境界面条件が得られる。

淡水域：

$$
\begin{aligned}
& n_{e} \frac{\rho_{1}}{\Delta \rho} \frac{\partial H_{1}}{\partial t}-n_{e} \frac{\rho_{2}}{\Delta \rho} \frac{\partial H_{2}}{\partial t}-\frac{\rho_{1}}{\Delta \rho} \frac{\gamma_{1}}{\mu_{1}}\left[k_{x}\left(\frac{\partial H_{1}}{\partial x}\right)^{2}+k_{y}\left(\frac{\partial H_{1}}{\partial y}\right)^{2}\right]+ \\
& \frac{\rho_{2}}{\Delta \rho} \frac{\gamma_{1}}{\mu_{1}}\left[k_{x} \frac{\partial H_{1}}{\partial x} \frac{\partial H_{2}}{\partial x}+k_{y} \frac{\partial H_{1}}{\partial y} \frac{\partial H_{2}}{\partial y}\right]-\frac{k_{y} \gamma_{1}}{\mu_{1}} \frac{\partial H_{1}}{\partial y}=0, y=h_{2}
\end{aligned}
$$

塩水域:

$$
\begin{aligned}
& n_{e} \frac{\rho_{1}}{\Delta \rho} \frac{\partial H_{1}}{\partial t}-n_{e} \frac{\rho_{2}}{\Delta \rho} \frac{\partial H_{2}}{\partial t}+\frac{\rho_{2}}{\Delta \rho} \frac{\gamma_{2}}{\mu_{2}}\left[k_{x}\left(\frac{\partial H_{2}}{\partial x}\right)^{2}+k_{y}\left(\frac{\partial H_{2}}{\partial y}\right)^{2}\right]- \\
& \frac{\rho_{1}}{\Delta \rho} \frac{\gamma_{2}}{\mu_{2}}\left[k_{x} \frac{\partial H_{1}}{\partial x} \frac{\partial H_{2}}{\partial x}+k_{y} \frac{\partial H_{1}}{\partial y} \frac{\partial H_{2}}{\partial y}\right]-\frac{k_{y} \gamma_{2}}{\mu_{2}} \frac{\partial H_{2}}{\partial y}=0, y=h_{2}
\end{aligned}
$$

一方, 自由水面に関する条件は, (6)式において, 大気圧 $q_{o}=0$, 空気の単位重量 $\gamma \simeq 0$ をそれぞれ $H_{1}, \gamma_{1}$ に代入することにより得られる。但し代入後あらためて $\gamma_{2}=\gamma_{1}, H_{2}=H_{1}, \mu_{2}=\mu_{1}$ と置く。

$$
-n_{e} \frac{\partial H_{1}}{\partial t}+\frac{\gamma_{1}}{\mu_{1}}\left[k_{x}\left(\frac{\partial H_{1}}{\partial x}\right)^{2}+k_{y}\left(\frac{\partial H_{1}}{\partial y}\right)^{2}\right]-\frac{k_{y} \gamma_{1}}{\mu_{1}} \frac{\partial H_{1}}{\partial y}=0
$$

\section{（iii）外部境界条件}

Fig-1 で示される外部塩・淡水域を共に静水域と仮定すると, 各境界上では, おのおの次の水頭値 をとる。

淡水汇関する境界条件：

境界 $C D: H_{C D}=h_{f}+h_{S O}$

$$
E F: H_{E F}=y
$$$$
F G: H_{F G}=\rho_{2} h_{S} / \rho_{1}-\Delta \rho y / \rho_{1}
$$

$$
\}
$$

塩水汇関する境界条件 :

境界 $A B: H_{A B}=\Delta \rho h_{S o} / \rho_{2}+\rho_{1}\left(h_{f}+h_{S o}\right) / \rho_{2}$ $B C: H_{B C}=\rho_{1}\left(h_{f}+h_{S o}\right) / \rho_{2}+\Delta \rho y / \rho_{2}$

$G H: H_{G H}=h_{S}$

$H A: \partial H / \partial n=0$

こ〉で, $n$ は不浸透性地盤に立てた外向法線を示す。

（2）定常解析

\section{(i) 支配方程式}

定常状態の塩・淡水内部境界面形状を解析する場合の支配方程式は，(1)式の時間に関する項を消去 
して，次のように表わせる。

$$
\frac{\partial}{\partial x}\left(K_{x i} \frac{\partial H_{i}}{\partial x}\right)+\frac{\partial}{\partial y}\left(K_{\mathrm{y} i} \frac{\partial H_{i}}{\partial y}\right)=q_{0 i}, i=1 \text { or } 2
$$

\section{（ii）塩・淡水境界面及び自由水面境界条件}

定常な内部境界面においては, この面を横切る水収支は存在せず, かつ塩, 淡水の圧力が連続す る。この条件から, 次式が成立する。

$$
\partial H_{i} / \partial n=0, i=1 \text { or } 2,
$$

こ〉で, $n$ は内部境界面上の法線を示す。

圧力連続条件より内部境界面の基準面からの高さ $h_{2} は(5)$ 式で与えられる。

自由水面に関しては, 内部境界面と同しく面を横切る水収支が存在しない。また大気圧 $q_{0}=0$ と すると, 自由水面上の水頭は位置水頭 $y$ に等しくなる。

$$
\partial H_{1} / \partial n=0, H_{1}=y
$$

こ〉で, $n$ は自由水面上の法線を示す。

外部境界条件に関しては，非定常解析で求めた(8)及び(9)式を用いる。

\section{2-2 混合塩淡水密度流}

Cooper, Kohout ら (1964)のマイアミ地域に打ける調查研究によると潮汐に起因する混合作用が卓 越する場合には，帯水層内で広範囲に渡って拡散帯が形成され，明瞭な内部境界面は存在してない。 帯水層へ侵入した塩水は先端部に执いて水体の往復運動により塩水に分散が生じ, その結果払散帯が 形成される。この扗散帯内では塩分濃度, 流体密度及び流速が相互に関連し, 濃度は流速に影響を与 えると同時に流速は濃度に影響を与える。この結果混合密度流は非常に複雑な不均質流体の挙動を呈 することになる。

\section{(1) 運動方程式}

帯水層内に乱ける流体流動が Darcy 法則に従らと仮定すると, 塩・淡水の実流速は次式で与兄ら る。

$$
\mathbf{V}=-\frac{k}{n_{e} \mu}(\nabla p+\rho g \nabla y)
$$

\section{（2）兵量保存式}

塩水に関する質量保存は(14)式で与えられる。

$$
\frac{\partial \rho}{\partial t}+\Delta \cdot(\rho \mathbf{V})=0
$$

上式において, 溶解塩分の移動は圧力変化の伝播に比して非常に遅いと考えられることから, 密度 の経時変化を表わす第 1 項は無視できると仮定する。

この結果(14)式は次式のように変形される。

$$
\nabla \cdot(\rho \mathrm{V})=\rho \nabla \cdot \mathrm{V}+\mathrm{V} \cdot \nabla \rho=0
$$


次に溶解塩分に関する保存式は,

$$
\frac{\partial \rho s}{\partial t}+\nabla \cdot\left(\rho_{s} \cdot V s\right)=0
$$

で与兄られる。この式の第 2 項中の $\rho_{s} \cdot V s$ は塩分の輸送が Fick 法則と同じ拡散型に從らと仮定す ると次式で表現できる。

$$
\rho_{s} \mathrm{~V} s=\rho_{s} \mathrm{~V}-D \cdot \nabla \rho_{s}
$$

こ〉で, $\rho_{s}$ : 溶解塩分の質量濃度, $\mathrm{V} s$ : 溶解塩分の実流速, $\mathrm{V}$ : 塩水の実流速, $D:$ 分散係数を表 わし, 分散係数 $D$ は流速, 分子拡散及び多孔質体の空隙形状と配置に支配される。

(17)式を(16)式に代入すると次の払散方程式が得られる。

$$
\frac{\partial \rho_{s}}{\partial t}+\rho_{s} \nabla \cdot \mathrm{V}+\mathrm{V} \cdot \nabla \rho_{s}-\nabla \cdot\left(D \cdot \nabla \rho_{s}\right)=0
$$

\section{（3） 状態方程式}

流速と塩分濃度とを連成させるため, 密度は塩分濃度の関数と考兄，次式で与える。

$$
\rho=\rho_{1}+(1-E) \rho_{s}
$$

こ〉に, $\rho_{1}$ は淡水密度, $E$ は定数で海水に対しては 0.3 の值をとる。

\section{3 重味付残差法による定式化}

非混合密度流及び混合密度流に関する, 前章において導いた基礎方程式を重味付残差法により定式 化を行ら。

本研究で使用した重味付残差法は, Galerkin 法である。この解析法の特徵は, 変分原理を導びき 出す必要がなく, 直接近似解が得られることにあり, 特に拓散問題に叔いては, 变分原理が存在しな いか, 明確な物理的意味を有する変分原理が得られないため重味付残差法が有力な解法となる。

重味付残差法を要約すると次の通りである。

原微分方程式の厳密解と近似解とは完全に一致せず何らかの残差 $\varepsilon_{i}$ が生ずる。この残差 $\varepsilon_{i}$ に解析 領域内で重味を付けて平均的に零となるように係数を決定する方法である。

また，Galerkin 法は重味に近似解として与えた補間関数を用いる方法である。

\section{3-1 非混合塩淡水密度流の定式化}

\section{(1) 非定常解析}

(1)式を重味付残差法を用いて定式化する。

$$
L_{1}(H)=S \frac{\partial H}{\partial t}-\frac{\partial}{\partial x}\left(k_{x} \frac{\partial H}{\partial x}\right)-\frac{\partial}{\partial y}\left(k_{y} \frac{\partial H}{\partial y}\right)+q_{0}=0
$$

こ〉で， $L_{1}$ は微分演算子を表わす。

上式中の水頭 $\mathrm{H}$ を次式で示す線形補間関数 $N i$ を用いて近似する。 


$$
\bar{H}=\sum_{i=1}^{4} N i(x, y) H_{i}
$$

ここで, 一は近似値を示し，また添字 $i$ は解析領域を多数の有限要素で分割した場合のおのおのの 要素の境界に位置する節点にとれぞれ Fig一 2 に示すごとく反時計回りに 1 から 4 まで通し番号を付 した節点を表わす。

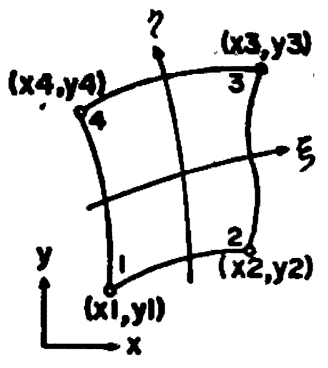

Descartes coordinate system

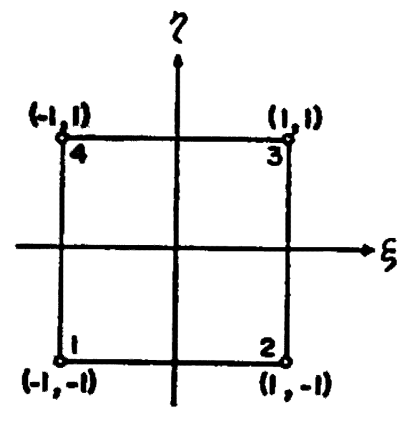

Naturd coordinate system

Fig-2 Isoparametric Element in Global and Local Coordinates.

本解析で用いた有限要素は取扱いが簡便な四節 点アイソパラメトリック要素であり，この要素は 要素形状を定めるために使用する節点数と，末知 関数を定義するのに使用される節点数が等しく, かつ使用する補間関数も同一である。この補間関 数はFig-2 に打ける右側の自然座標系の $\xi ， \eta$ 軸が左側の歪んだ全体座標系へ写像した場合，座 標軸は，曲るが相互の関係は保持されるように選 ぶ。

四節点アインパラメトリック要素を使用した場合の補間関数は $N i$ 次式で与えられる。

$$
N i=\frac{1}{4}(1+\xi \xi i)(1+\eta \eta i)
$$

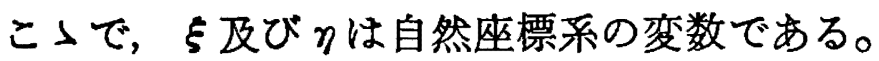

(21)式で与えられる水頭の近似值を(20)式に代入すると零とはならず残差 $\varepsilon_{1}$ が生ずる。

$$
\varepsilon_{1}=L_{1}(H) \neq 0
$$

この残差 $\varepsilon_{1}$ に重味 $N i$ を付けて解析領域内 $R$ で積分し零とする。

$$
\int_{R} \varepsilon_{1} N i d R=0
$$

この結果, 次式が得られる。

$$
[\mathbf{A}]\{\mathbf{H}\}+[\mathbf{B}]\{d H / d t\}=\{\mathbf{F}\}
$$

ここに,

$$
\begin{aligned}
& A_{i j}=\iint_{R}\left\lceil K_{x} \frac{\partial N_{i}}{\partial x} \frac{\partial N j}{\partial x}+K_{y} \frac{\partial N_{i}}{\partial y} \frac{\partial N j}{\partial y}\right] d x d y \\
& B_{i j}=\iint_{R} S N_{i} N j d x d y \\
& F i=\iint_{R} q_{o} N_{i} d x d y+\int_{S} q_{n} N_{i} d s
\end{aligned}
$$

ここで， $q_{n}$ は境界 Sの単位長さ当りの流速を示す。

(25)式中には時間微分が含まれており，有限要素法は空間離散化には非常に有効な方法であるが，時 間離散化には差分法が一般に簡便でため，本解析では次の陽解法を用いた。 


$$
([\mathbf{A}]-(1 / \Delta t)[\mathbf{B}])\{H\}_{t}+(1 / \Delta t)[\mathbf{B}]\{\mathbf{H}\}_{t+4 t}=\{\mathbf{F}\}_{t}
$$

こ〉で， $t$ は任意時刻， $\Delta t$ は時間刻みを示す。

(2) 定常解析

定常塩・淡水密度流に関する，支配方程式の定式化は次式で与えられる。

$$
[\mathbf{A}]\{\mathbf{H}\}=\{\mathbf{F}\}
$$

こ〉で，A 及び F の各要素は(26)，(28)式で与えられたものと同一である。 定常解析では Fig一-3に示す方法で是体を分割し，圧力が急变する部分の解析精度の向上を図っ

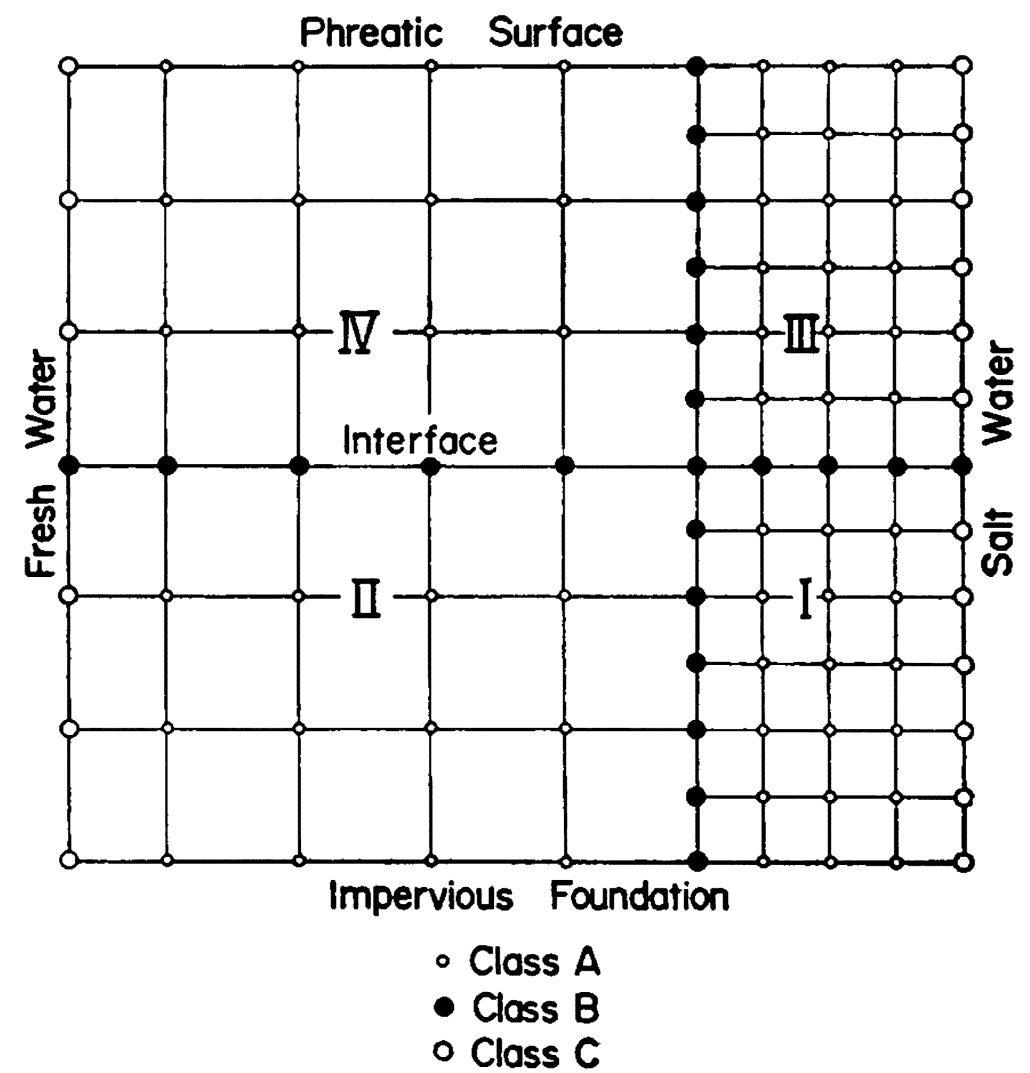

Fig-3 Finite Element Mesh for Steady-State Immiscible Interface Problem.

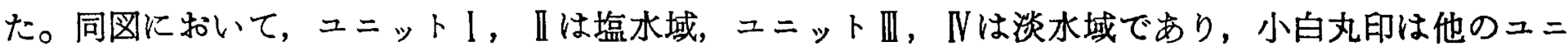
ットに接続していない内部節点（Class A)，黒丸印は各ニニットの接続節点（Class B)，白丸印は水 頭値が既知である節点（Class C) をそれぞれ表わす。

塩水域のニニットにI打活る支配方程式(30)は次のように表わすことができる。但し添字は節点種類 及びュニット番号を示す。

$$
\left[\begin{array}{lll}
A_{A A I} & A_{A B I} & A_{A C I} \\
A_{B A I} & A_{B B I} & A_{B C I} \\
A_{C I I} & A_{C B I} & A_{C C I}
\end{array}\right]\left\{\begin{array}{l}
H_{A I} \\
H_{B I} \\
H_{C I}
\end{array}\right\}=\left\{\begin{array}{l}
F_{A I} \\
F_{B I} \\
F_{C I}
\end{array}\right\}
$$

(31)式を変形し，接続節点上の水頭 $\left\{H_{B}\right\}$ を求める。

$$
\begin{aligned}
& {\left[\begin{array}{lll}
A_{B B I}-A_{B A I} & A_{A A I}^{-1} & A_{A B I}
\end{array}\right]\left\{H_{B I}\right\}} \\
& =\left\{F_{B I}\right\}-\left(A_{B A I} A_{A A I} I^{-1}\right)\left\{F_{A I}\right\}+\left[A_{B A I} A_{A A I} I^{-1} A_{A C I}-A_{B C I}\right]\left\{H_{C I}\right\}
\end{aligned}
$$


同様に塩水域のニニット【に関して次式が成立する。

$$
\begin{aligned}
& {\left[A_{B B I I}-A_{B A I I} A_{A A I I}{ }^{-1} A_{A B I I}\right]\left\{H_{B I I}\right\}} \\
& =\left\{F_{B I I}\right\}-\left(A_{B A I I} A_{A I I}{ }^{-1}\right)\left\{F_{A I I}\right\}+\left[A_{B A I I} A_{A I I I}{ }^{-1} A_{A C I I}-A_{B C I I}\right]\left\{H_{C I I}\right\}
\end{aligned}
$$

以上誘導した(32)及び(33)式を重合わせることにより接続節点に縮約された方程式が求まるが、ユニッ ト】とユニットIは境界上に打いて節点が一部共有されないため, 補間法を用いて連続させる。 (32)及び(33)式を次のよ5に書きかえる。

$$
\left(A_{U I}\right)\left\{H_{B I}\right\}=\left\{F_{U_{I}}\right\}
$$

但し, $\quad\left(A_{U I}\right)=\left[\begin{array}{lll}A_{B B I}-A_{B A I} & A_{A A} I^{-1} & A_{A B I}\end{array}\right]$

$$
\begin{aligned}
& \left\{F_{U I}\right\}=\left\{F_{B I}\right\}-\left(A_{B A}-A_{A A I}{ }^{-1}\right)\left\{F_{A I}\right\}+\left[A_{B A I} A_{A I} I^{-1} A_{A C I}-A_{B C I}\right] \\
& \left\{H_{C I}\right\}\left(A_{U I I}\right)\left\{H_{B I I}\right\}=\left\{F_{U I I}\right\}
\end{aligned}
$$

但し, $\quad\left(A_{U I I}\right)=\left[A_{B B I I}-A_{B A I I} A_{A A I I} A_{A B I I}\right]$

$$
\left\{F_{U I I}\right\}=\left\{F_{B I I}\right\}-\left(A_{B A I I} A_{A A I I} A_{A B I I}^{-1}\right)\left\{F_{A I I}\right\}+\left[A_{B A I I} A_{A A I}{ }^{-1}\right.
$$$$
\left.A_{A C I I}-A_{B C I I}\right]\left\{H_{C I I}\right\}
$$

ユニット【の接続節点值をニニット【の接続節点值に補間した方程式を次式のようにおく。

$$
\overline{\left(A_{O I}\right)} \overline{\left\{H_{B I}\right\}}=\overline{\left\{F_{U I}\right\}}
$$

ただし， $\left\{H_{B I}\right\}=\left[H_{\mathbb{Q}}\right]\left\{\overline{\left.H_{B I}\right\}}\right.$

$$
\overline{\left\{F_{U I}\right\}}=\left[H_{\rho}\right]\left\{F_{U I}\right\}
$$

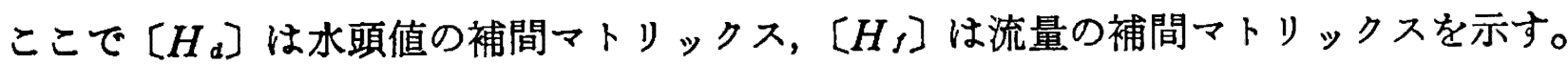
ニニット1の接続境界上のポテンシャル・エネルギーは,

$$
X_{U I}=\frac{1}{2}\left\{H_{B I}\right\}^{T} A_{U I}\left\{H_{B I}\right\}-\left\{H_{B I}\right\}^{T}\left\{F_{U I}\right\}
$$

ニニット』の接続境界上に補間されたポテンシャル・エネルギーは, (36)式から

$$
\bar{X}_{U I}=\frac{1}{2}\left(\left[H_{d}\right]\left\{\overline{H_{B I}}\right\}\right)^{T} A_{U I}\left(\left[H_{d}\right]\left\{\overline{H_{B I}}\right\}\right)-\left(\left[H_{d}\right]\left\{\overline{H_{B I}}\right\}\right)^{T}\left\{F_{U I}\right\}
$$

(38)式を変分して補間後の方程式を求める。

$$
\delta \bar{X}_{U I}=\left[H_{d}\right]^{T} A_{U I}\left[H_{d}\right]\left\{\overline{H_{B} I}\right\}-\left[H_{d}\right]^{T}\left\{F_{U I}\right\}
$$

(36)及び(39)式から次の関係が得られる。

$$
\begin{aligned}
& \left(\overline{\left.A_{U I}\right)}=\left[H_{d}\right]^{T} A_{U I}\left[H_{d}\right]\right. \\
& \left\{\overline{\left.F_{U I}\right\}}=\left[H_{d}\right]^{T}\left\{F_{U I}\right\}\right. \\
& {\left[H_{f}\right]=\left[H_{d}\right]^{T}}
\end{aligned}
$$

以上の結果から， $\left\{\overline{H_{B I}}\right\}=\left\{H_{B I}\right\}$ として(36)式に代入すると, 


$$
\left[H_{d}\right]{ }^{T} A_{U I}\left[H_{d}\right]\left\{H_{B I}\right\}=\left[H_{d}\right]^{T}\left\{F_{U I}\right\}
$$

が得られこれと(35)式とを重合わせると共有する節点に縮約された方程式が得られる。

$$
\begin{aligned}
& {\left[\left[H_{d}\right]^{T}\left[A_{B B I}-A_{A B I} A_{A A I}{ }^{-1} A_{A B I}\right]\left[H_{d}\right]+\left[A_{B B I I}-A_{B A I I} A_{\triangle A I I}{ }^{-1} A_{A B I I}\right]\right]\left\{H_{B I I}\right\}} \\
& =\left[H_{d}\right]^{T}\left[\left\{F_{B I}\right\}-\left(A_{B A I} A_{A I}{ }^{-1}\right)\left\{F_{A I}\right\}+\right. \\
& \left.\left(A_{B A I} A_{A A I} A_{A C I}-A_{B C I}\right)\left\{H_{C I}\right\}\right]+\left\{F_{B I I}\right\}-\left(A_{B A I I} A_{A A I I}{ }^{-1}\right)\left\{F_{A I I}\right\} \\
& +\left(A_{B A I I} A_{A A I I} A_{A C I I}-A_{B C I I}\right)\left\{H_{C I I}\right\}
\end{aligned}
$$

(44)式を解いて $\left\{H_{B I I}\right\}$ を決定し, 後退代入により， $\left\{H_{B I}\right\}=\left[H_{d}\right]\left\{H_{B I I}\right\}$ から $\left\{H_{B I I}\right\}$ を求め (311)式で $\left\{H_{A_{I}}\right\}$ を決定する。同様にして $\left\{H_{A_{I I}}\right\}$ を求める。この様にして得られた淡・塩水領域の水 頭値を用いて(5)式により塩・淡水内部境界面位置を決め, 圧力の連続を調べ許容值以外であれば内部 境界面を移動して, 許容値以内になるまで上述の操作を綝返す。非定常解析の場合には，与えられた 初期条件及び境界条件を用いて時間刻み毎に水頭值を求め(6)式により内部境界面の移動量を計算す る。但し非定常解析に用いた要素はニニット【及び $\mathbb{N}$ 要素である。

\section{2-3 混合塩淡水密度流の定式化}

混合密度流に関する定式化は，前述の非混合密度流の場合々同様な手法による。

(13)，(15)及び(18)式を次のよ5に変形する。

$$
\begin{aligned}
& L_{2}(\mathbf{V}, q)=\mathbf{V}+\frac{k}{n_{\mathrm{e}} \mu}(\nabla p+\rho g \nabla y)=0 \\
& L_{3}(\mathbf{V}, \rho)=\rho \nabla \cdot \mathbf{V}+\mathbf{V} \cdot \nabla \rho=0 \\
& L_{4}(\mathbf{V}, C)=\frac{\partial C}{\partial C}+C \nabla \cdot \mathbf{V}+\mathbf{V} \cdot \nabla C-\nabla \cdot(D \cdot \Delta C)=0
\end{aligned}
$$

(47)式に拈いて，Cは質量濃度 $\rho_{S}$ と同一で，以後 $C$ を用いる。

求めるべき流速，压力及び塩分濃度の近似解を，補間関数 $N_{\iota}$ を用いて次式で定義する。

$$
\begin{aligned}
& \overline{\mathbf{V}}=\sum_{i=1}^{4} N_{i}(x, y) \mathbf{V}_{i} \\
& \bar{p}=\sum_{i=1}^{4} N_{i}(x, y) q_{i} \\
& \bar{C}=\sum_{i=1}^{4} N_{i}(x, y) C_{i}
\end{aligned}
$$

(48)～(50)式を各々(45) 〜(47)式に代入し，解析領域で積分を行って残差 $\epsilon_{i}$ を零にする。

$$
\begin{aligned}
& \varepsilon_{2}=L_{2}(\overline{\mathbf{V}}, \bar{p}) \neq 0 \\
& \varepsilon_{3}=L_{3}(\overline{\mathbf{V}}, \rho) \neq 0 \\
& \varepsilon_{4}=L_{4}(\overline{\mathbf{V}}, C) \neq 0 \\
& \int_{R} \varepsilon_{2} N_{i} d R=0 \\
& \int_{R} \varepsilon_{3} N_{i} d R=0 \\
& \int_{R} \varepsilon_{4} N_{i} d R=0
\end{aligned}
$$

以上の結果，(54)，(55)式をまとめてマトリックス表示を行うと，次式が得られる。 
$[\mathbf{A}]\{\mathbf{X}\}=\{\mathbf{F}\}$

ここで,

$$
\begin{aligned}
& A_{i j}=\iint_{R}\left(\begin{array}{ccc}
\sum_{k=1}^{4}\left(\rho_{k} N_{k} \frac{\partial N_{j}}{\partial x}+\rho_{k} \frac{\partial N_{k}}{\partial x} N_{j}\right) N_{i} & \sum_{k=1}^{4}\left(\rho_{k} N_{k} \frac{\partial N_{j}}{\partial y}+\rho_{k} \frac{\partial N_{k}}{\partial y} N_{j}\right) N_{i} & 0 \\
N_{i} N_{j} & 0 & N_{i} \frac{k}{n_{e} \mu} \frac{\partial N_{j}}{\partial x} \\
0 & N_{i} N_{j} & N_{i} \frac{k}{n_{e} \mu} \frac{\partial N_{j}}{\partial y}
\end{array}\right) d x d y \\
& X_{i}=\left\{\begin{array}{c}
u_{i} \\
v_{i} \\
q_{i}
\end{array}\right\} \quad F_{l}=\left\{\begin{array}{l}
0 \\
0 \\
-\iint_{R} N_{i} \frac{k g}{n_{\mathrm{e}} \mu} \sum_{k=1}^{4} \rho_{k} N_{k} d x d y
\end{array}\right\}
\end{aligned}
$$

上式中，添字 $i ， j ， k$ は一要素内の節点にそれぞれ反時計回りに通し番号を付した節点を示す。 uiは水平実流速， $v_{i}$ は鉛直実流速であり， $N_{i}, N_{j}$ 及び $N_{k}$ は前述の(22)式で定義された補間関数であり， すべて同一のものである。また密度 $\rho_{k} N_{k}$ は, 要素の四節点上の濃度值を(19)式により密度に変換し，こ の四節点上の密度を用いて，(48) (50)式と同一の多項式により要素内の任意点の密度を求める。

即ち $\rho=\sum_{k=1}^{4} \rho_{k} N_{k}$

同様に拡散方程式(56)式に関して次式が得られる。

$[\mathbf{B}]\{\mathbf{C}\}+[\mathbf{D}]\{d c / d t\}=\{\mathbf{G}\}$

ここで,

$$
\begin{aligned}
B_{i j}= & \iint_{R}\left[\sum_{k=1}^{4}\left\{\left(u_{k} \frac{\partial N_{k}}{\partial x}+v_{k} \frac{\partial N_{k}}{\partial y}\right) N_{j} N_{i}+\left(u_{k} N_{k} \frac{\partial N_{j}}{\partial x}+v_{k} N_{k} \frac{\partial N_{j}}{\partial y}\right) N_{i}\right\}+\right. \\
& \left.\left(D_{x} \frac{\partial N_{j}}{\partial x} \frac{\partial N_{i}}{\partial x}\right)+\left(D_{y} \frac{\partial N_{j}}{\partial y} \frac{\partial N_{i}}{\partial y}\right)\right] d x d y \\
D_{i j}= & \iint_{R} N_{i} N_{j} d x d y, \quad G_{i}=\int_{S} V_{m} \cdot n N_{i} d S
\end{aligned}
$$

上式中, $V_{\mathrm{m}}$ は境界 $S$ を横切る質量流束を示す。

払散問題において，方程式は非線形となりその上に塩分濃度と流速は連鎖関係を有するため(57)式と (59)式を(19)式を介して連成させ繰返し法により解を収束させなければならない。

計算過程を説明すると，

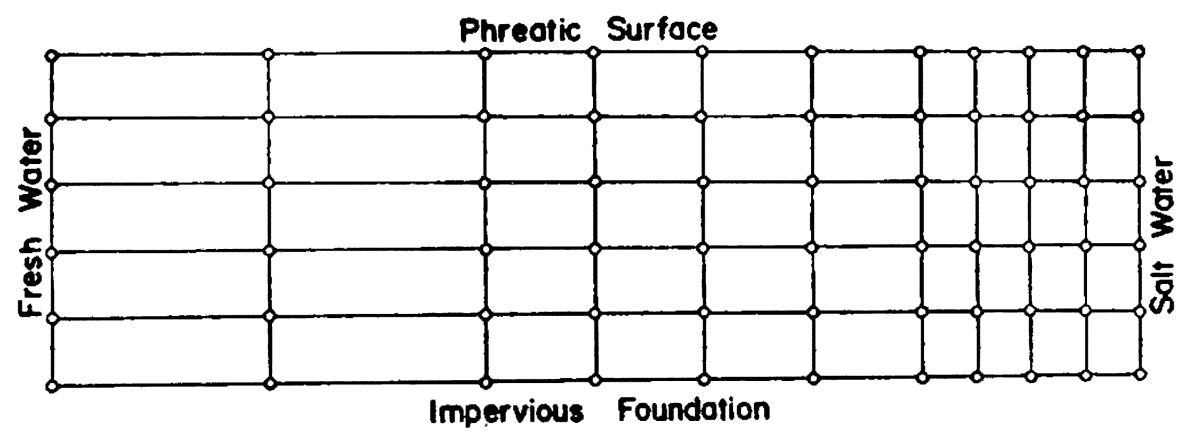

Fig- 4 Finite Element Mesh for Dispersion Problem. 
（i）帯水層を四節点アイソパラメトリック要素で分割を行ら。Fig-4は本解析で用いた分割様式 を示し，濃度変化が大きいと予測される部分は他の部分より細分割している。

（ii）各節点に初期濃度を与光，(57)式により水平，鈶直両実流速成分を决定する。

（iii）得られた流速を(59)式に代入し，陽解法を用いて濃度を求める。流速と新しく求まった濃度と は適合しない。

（iv）求まった濃度を用いて再び流速を計算する。この流速から濃度を決定する。濃度が一定の詁 容値以内の変動差に入るまで (ii)〜 (iii) の手法を繰返す。

（v）濃度が決定したならば次の時刻に移る。

この計算過程に拉いて(57)式の連立一次方程式を Sweep out 法で解くにあたり、マトリックス[A] の対角項に零要素が存在するため，再配列して計算しなければならない。

また，(29)，(30)，(57)及び(59)式中に拈ける積分は直接行らことができないため本解析では Gauss の 〔3×3] 求積法を用いて計算した。

\section{4. 非混合塩淡水密度流実鍳}

数値計算で得られた結果を検証するため, Hele一Shaw モデルにより実験を行った。

モデルはガラス製の通水部と透明アクリル製の定水頭槽から成り立っている。モデルの大きさは, 通水部が高さ300 mm，長さ300mmで二枚の平行板の間隔は液体の毛管作用を出来る限り抑えるため2.7 m $\mathrm{m}$ とた。この通水部の両端には幅 $150 \mathrm{~mm}$, 長さ $180 \mathrm{~mm}$, 高さ $300 \mathrm{~mm}$ の定水頭水槽が付設され, 実験条 件に合せて可動ぜキにより任意の水深が保持できる構造になっている。実験用液体は互に混合しない ものを選び，淡水として比重0.876の流動パラフィン，塩水として比重1.015のC.M. C（カルボキシ ル・メチル・セルローズ） $2 \%$ 溶液を用いた。

この二液体をそれぞれ二台の粘性ポンプ（宮本製作所製 CP-35）により定水頭水槽に流送し，その 後通水部にて非混合密度流を発生させた。

被圧帯水層の実験には, $2.7 \mathrm{~mm}$ 厚のゴム板を通水部上方から挿入し固定する方法を採用した。

この実験で使用した両液体は，一般に巨大分子が液状として存在するため非ニニートン流を呈する といわれている。実験での流動を検討するため, 実験装置の通水部にゴム板を挿入し幅 $2.7 \mathrm{~mm}$, 高さ $10 \mathrm{~mm}$ の矩形通水部を設け，種々の動水勾配で液体を流動させ同時に温度及び流量を湘定した。

この矩形水路における平均流速 Um は次式で与えられる。

$$
u_{\mathrm{m}}=\frac{\tau^{\mathrm{e}}}{\mu} \frac{1}{\mathrm{e}+1} \frac{\mathrm{b}}{3}
$$

ここで， $\mu$ は粘性係数，ては剪断応力，eはレオロジ一定数， b は通水部の二平板間隔を表わす。

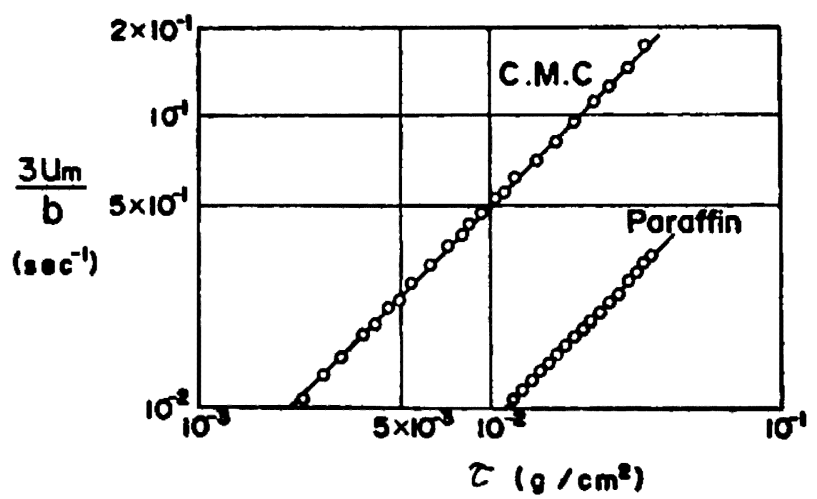

Fig- 5 Rates of Flow between Parallel Plates for C. M. C. and Paraffin. 
実験の結果， $u_{\mathrm{m}}$ とてはFig-5K示す直線関係を有する。この直線の勾配から e = 1 が得られ，実 験で行った動水勾配での流動はニュートン流であると考えられる。

この装置の透水係数 $\mathrm{K}_{i}$ は，次式で定義される。

$$
K_{i}=\frac{b^{2} \gamma_{i}}{12 \mu_{i}}(i=1,2)
$$

ここで, 添字 $i=1$ はパラフィン, $i=2$ は C.M.C を示す。 $20^{\circ} \mathrm{C}$ におけるパラフィン, C. M .C $2 \%$ 溶液の粘性係数はそれぞれ， $\mu_{1}=1.2 \times 10^{-3} \mathrm{~g} . \mathrm{s} / \mathrm{cm}^{2}, \mu_{2}=4.0 \times 10^{-4} \mathrm{~g} . \mathrm{s} / \mathrm{cm}^{2}$ である。

これらの值を用いて透水係数 $K_{i}$ を求めると， $K_{1}=4.39 \mathrm{~cm} / \mathrm{sec} ， K_{2}=15.11 \mathrm{~cm} / \mathrm{sec}$ がそれぞれ得られ る。

実験において, 内部境界面形状は35mmカラ（日本光学製 $\mathrm{F}-\mathbb{I}$ ) で記録し, 流量は $100 \mathrm{cc}$ メスシ リンダーで一定時間採水して決定した。

\section{5 解析結果及び考察}

\section{5-1 非混合塩淡水密度流}

\section{(1) 定常不圧密度流}

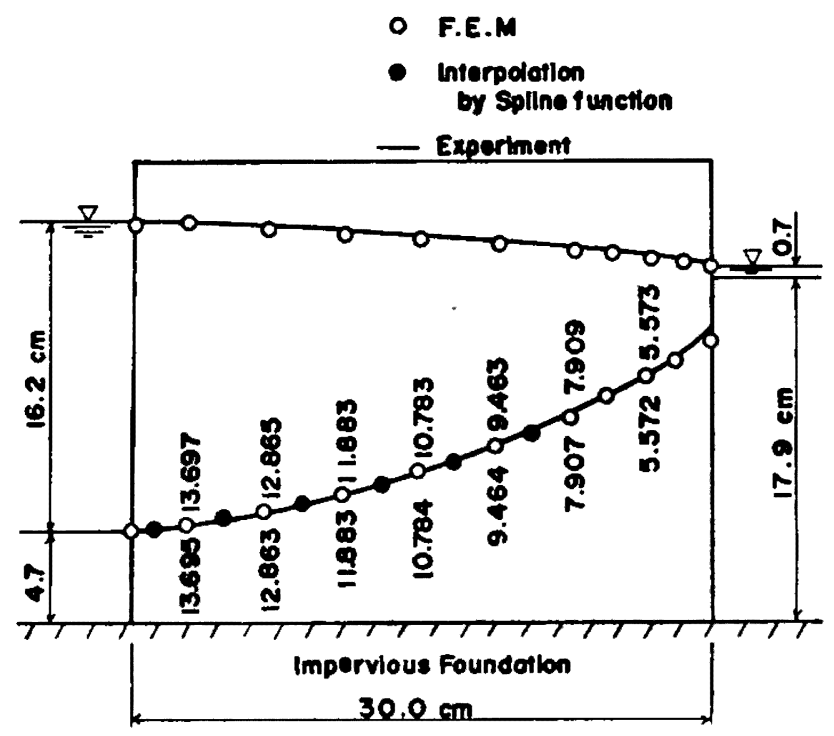

Fig-6 Steady-State Phreatic Surface and Salt-water Interface Solution.

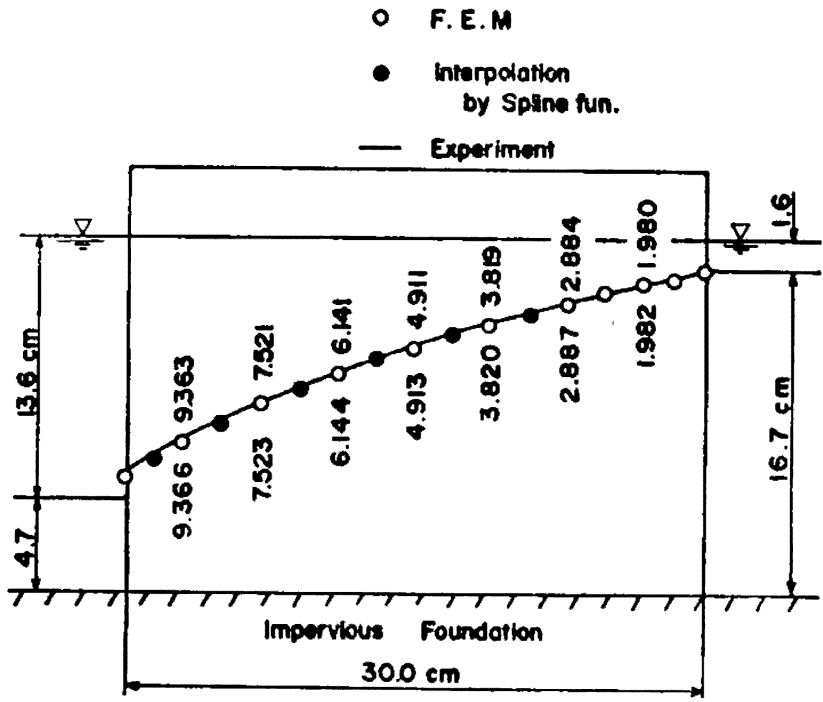

Fig-7 Steady-State Phreatic Surface and Salt-water Interface Solution.

定常不王密度流解析例を Fig-6，7 亿示す。これらは，外側淡水域及び塩水域の境界条件が与え られた場合，堤体内に怙ける内部境界面の位置及び形状をFig-3に示す分割法で（30）式を用いて 求めたもので，計算当初に沏いて内部境界面は水平に与えている。

Fig-6は外側淡水域の水深が塩水域の水深より大きな場合である。但し右側の塩水域に扣ける塩 水上の $0.7 \mathrm{~cm}$ 淡水は実験条件と合致させるため，モデル内から流出して貯留された淡 水の水深をそ のまま作用させている。

この場合，淡水の流動が塩水のそれより卓越し内部境界面形状は下に凸の放物線形をとる。また解 析結果は実験結果を非常に高い精度で推測できることが認められる。なお，同図において白丸は解析 值，黒丸はこれらの値をSpline関数で補間した值を示す。 
内部境界面に沿って記載されている数值は解析で境界面を決定した際の圧力を示すもので, 上段が 淡水，下段が塩水の圧力を表わす。これらの数值を比較すると圧力は連続していることが認められ る。

次に単位幅当りの流量に関して，解析値と実験值とを比較する。

\section{淡水流量塩水流量}

実験値 $\quad 0.602 \mathrm{~cm}^{3} / \mathrm{sec} / \mathrm{cm} \quad 0.126 \mathrm{~cm}^{3} / \mathrm{sec} / \mathrm{cm}$

解析值 $0.580 \mathrm{~cm}^{3} / \mathrm{sec} / \mathrm{cm} \quad 0.131 \mathrm{~cm}^{3} / \mathrm{sec} / \mathrm{cm}$

流量に関する相対誤差は約 $4 \%$ である。

Fig一 7 は淡水域と塩水域との水位を等しくした境界条件で，内部境界面形状及び位置を求めたる のである。この場合淡水は静止状態で，塩水のみが密度差により淡水域まで流動し境界面は上に凸の 形状を呈する。

単位幅当りの流量は,

\section{塩水流量}

実験值 $\quad 3.632 \mathrm{~cm}^{3} / \mathrm{sec} / \mathrm{cm}$

解析值 $3.478 \mathrm{~cm}^{3} / \mathrm{sec} / \mathrm{cm}$

が得られ，前例と同じく相対誤差は約 $4 \%$ である。

Fig一6，7で得られた内部境界面形状を考察するため，簡単化した内部境界面の一部を Fig一 8 に 示す。同図に颃いて，境界面に沿ら淡水及び塩水の浸透

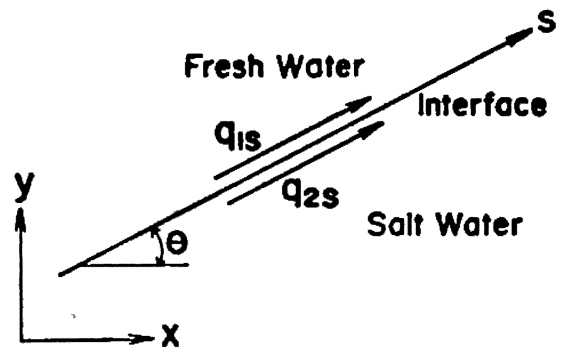

Fig- 8 Segment of Stationary Interface. 流速をそれぞれ $q_{1} s ， q_{2} s$ とすると，これらは次式で定 義される。

$$
\begin{aligned}
& q_{1 s}=-\frac{k \gamma_{1}}{\mu_{1}} \frac{\partial}{\partial s}\left(\frac{p}{\gamma_{1}}+y\right) \\
& q_{2 s}=-\frac{k \gamma_{2}}{\mu_{2}} \frac{\partial}{\partial s}\left(\frac{p}{\gamma_{2}}+y\right)
\end{aligned}
$$

内部境界面上では淡・塩水の圧力が連続しなければなら ないことから，(62）式に拈いて $\partial \mathrm{p} / \partial \mathrm{s}$ を消去して $\partial \mathrm{y} / \partial \mathrm{s}$ を求めると次式が得られる。

$$
\frac{\partial y}{\partial s}=\sin \theta=\frac{q_{1} s \mu_{1}-q_{2} s \mu_{2}}{k\left(\gamma_{2}-\gamma_{1}\right)}
$$

ここで， $\theta$ は水平軸と内部境界面との交角を表わす。

Fig一 6 に打いて, $\left.q_{1} s\right\rangle 0, q_{2 s}\left\langle 0, \gamma_{2}\right\rangle \gamma_{1}$ の条件より, $\sin \theta>0$ が得られる。これは淡水の流動方 向に内部境界面が上昇することを意味し，淡水流速が増加するにつれて交角 $\theta$ が増加し内部境界面の 上昇量が大さくなる。一方，Fig一 7 の条件は， $q_{1}=0, q_{2 s}>0$ であるから（63）式は

$$
\frac{\partial y}{\partial s}=\sin \theta=-\frac{q_{2 s} \mu_{2}}{k\left(\gamma_{2}-\gamma_{1}\right)}>0
$$

となり，塩水の流動方向に内部境界面は下降する。塩水流速が増加するにつれて交角 $\theta$ が増加し内部 境界面は流動方向に降下量が大きくなる。

Fig一 6,7の解析例では，以上の内部境界面の特性を十分に表現できることが認められる。

(2) 定常被圧密度流

自由水面が存在しない被圧状態に拈ける塩淡水内部境界面解析の一例をFig一 9 に示す。同図にお 


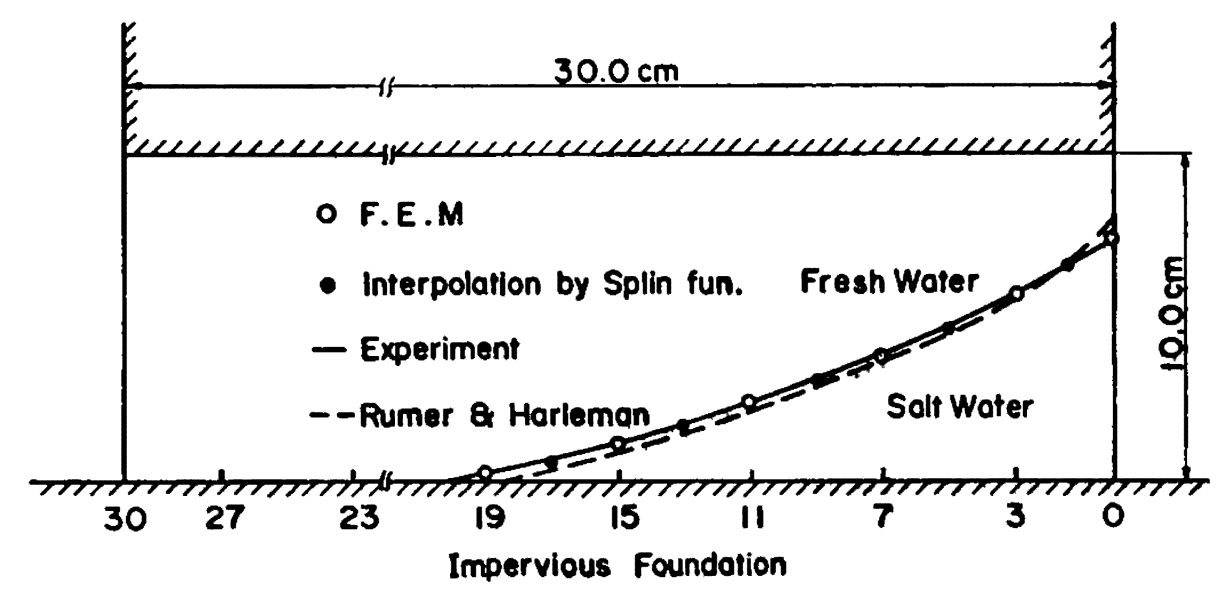

Fig-9 Steady-State Salt-water Interface in Confined Aquifer.

いて, 左方外部淡水域の水深を $17,5 \mathrm{~cm}$, 右方塩水域の水深を $14.3 \mathrm{~cm}$ とた境界条件の下での内部境界 面形状及び位置を示す。この解析例に怙ける堤体は, 長さが $30 \mathrm{~cm}$, 高さが $10 \mathrm{~cm}$ であので流れが準一 様流に近いと考えることができるため，堤体の要素分割は Fig一 3 で示したュニット【及びNの同一 要素を用いて解析を行った。

同図中には，準一様流理論に基づくRumer，Harleman による解析結果も同時に揭げてある。こ の境界条件に和いては，両解析結果には大きな異差はない。但し，Rumer らの解法はあらかじめ淡 水流量が既知でなければ解析が行えないため，本例では実験流量值を用いた。

解析結果と実験結果を比較すると以下のようになる。

\section{解析値}

塩 水クサビ 長 $21.0 \mathrm{~cm}$

$x=0 \mathrm{~cm}$ に打恰水高

$7.4 \mathrm{~cm}$

淡水流量

$1.53 \mathrm{~cm}^{3} / \mathrm{sec} / \mathrm{cm}$
実験値

$21.5 \mathrm{~cm}$

$7.5 \mathrm{~cm}$

$1.56 \mathrm{~cm}^{3} / \mathrm{sec} / \mathrm{cm}$

以上被圧密度流に沶いても，解析值と実験值とは精度良く一致することが確認される。

\section{（3）非定常不圧密度流}

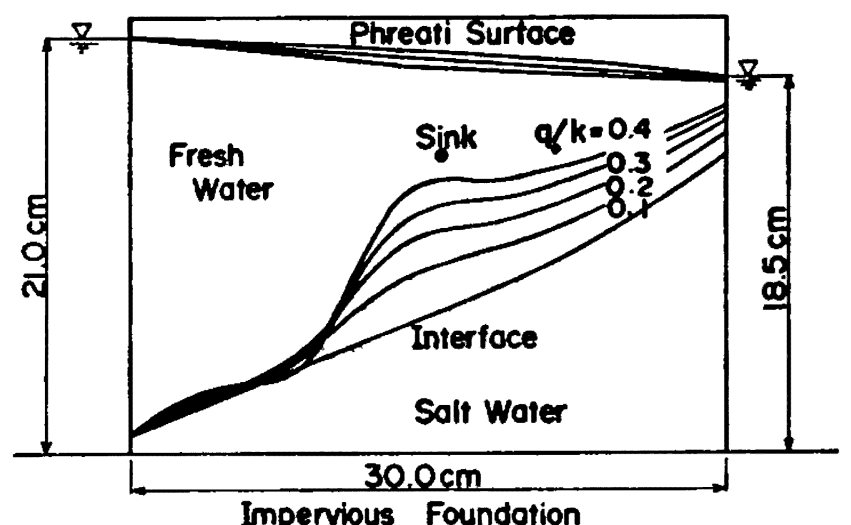

Fig-10 Steady-State Interface with Pumping.

Fig一-10は堤体中央部の高さ $15.75 \mathrm{~cm}$ 点に 扎いて種々の強さで揚水を行った場合の境界面 形状を示するのである。初期条件の内部境界面 形状は定常解析により無揚水の内部境界面を求 めて決定した。また揚水量 $q_{0}$ は任意の透 水係 数 $k$ に対応できるように比 $q_{0} / k$ をとり，この值 を 0 から $0.4 \mathrm{~cm}^{-1}$ の範囲で変化させた。揚水量 が大さくなる程, 淡水は加速されて揚水口に向 い,このため淡水域に拈いては压力が降下し， その結果境界面が上昇して upcorn が形成さ れる。同時に自由水面が降下し揚水地点から塩

域水までの勾配が緩くなり，塩水侵入が促進される。

初期条件から定常状態に達するまでに要する時間は $\mathrm{t} \fallingdotseq 18$ 分 $\left(q_{0} / k=0.1\right), \mathrm{t} \doteqdot 14$ 分 $\left(q_{0} / k=0.2\right)$, $\mathrm{t} \fallingdotseq 8$ 分 $\left(q_{0} / k=0.3\right)$ 及び $\mathrm{t} \fallingdotseq 3$ 分 $\left(q_{0} / k=0.4\right)$ であった。 


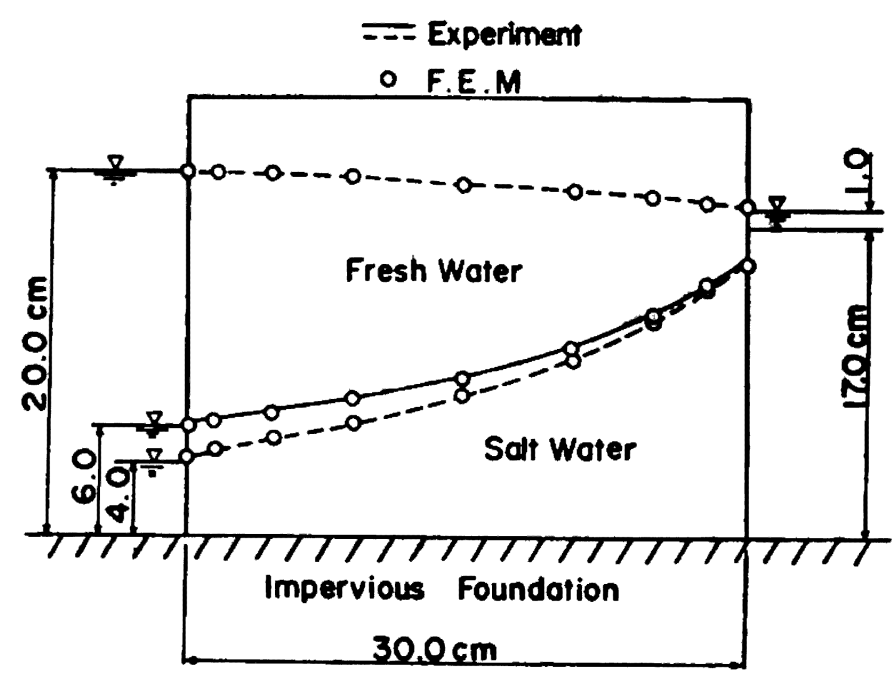

Fig-11 Displacement of Interface in Unconfined Aquifer.

Fig-11 は淡水域に存在する塩水の水深 が4.0 $0 \mathrm{~cm}$ から6.0 $\mathrm{cm}$ に増加した場合の内部境界 面の移動を示す。この解析では, 淡水域の塩 水深か $4.0 \mathrm{~cm}$ の場合を定常解析で求めて初期 条件とした。非定常解析では急速に塩水深を $6.0 \mathrm{~cm}$ に上昇させ, 左方堤体面の塩水部分の ポテンシャル值を変化させる。この場合境界 面上の水頭値を $\Delta \mathrm{t}$ 前に固定して塩，淡水域の 水頭值を求め，これを用いて内部境界面の鉛 直，水平速度を決め， $\Delta \mathrm{t}$ を乗じて移動量を算 定する。この際, 塩水及び淡水の移動量に異 差が生ずるので，本解析では，両者の平均を とって移動位置とした。また境界面が移動す るため塩, 淡水の領域が变化するが，本解析 に招いては，塩水域では不浸透層から内部境界面までの鉛直距離を算出し，淡水域では内部境界面か ら自由水面をでの鉛直距離を算出してこの距離を要素数で等分割して改めて要素の寸法を決定し再分 割を行ら。このような操作で， $\Delta \mathrm{t}=0.1$ 秒ずつ解析し3.0秒後の定常状態に達するまで繰返し境界面位 置を追跡した。

\section{5,-2 混合塩淡水密度流}

Fig-12 は臨海域の帯水層を単純化し，その層内での塩水払散解象を解析したものである。

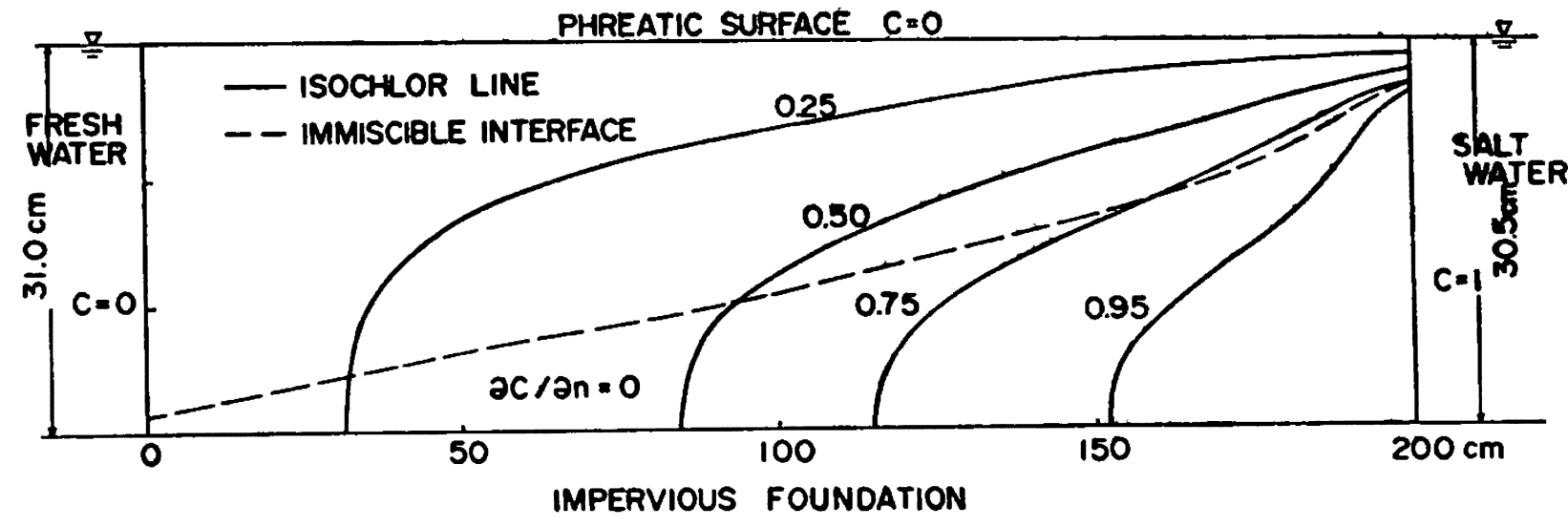

Fig-12 Steady-State Concentration Distribution.

本解析に特いて使用した帯水層及び流体の特性は以下に示す通りである。

横方向分散係数 $D_{X}=0.02 \mathrm{~cm}^{2} / \mathrm{sec}_{0}$

緃方向分散係数 $D_{Y}=0.002 \mathrm{~cm}^{2} / \mathrm{sec}_{\text {。 }}$

透水係数 $K=0.29 \mathrm{~cm} / \mathrm{sec}_{0}$ 。

淡水密度 $\rho_{1}=1.000 \mathrm{~g} / \mathrm{cm}^{3}$ 。

塩水密度 $\rho_{2}=1.025 \mathrm{~g} / \mathrm{cm}^{3}$ 。

な怙，同図中の濃度 Cは次式により無次元表示を行っている。

$C=C / C_{S}$ 
但し，CS

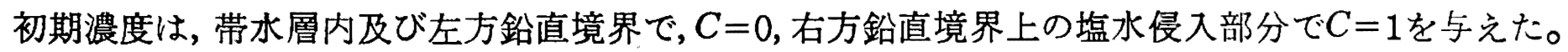
同図中には，塩・淡水の拡散の有無により現象がいかに異なるかを比較する目的で前述の非混合密度 流解析の結果も併せて揭げている。

Fig-13は Fig-12 の解析に拈ける塩・淡水流向を示するので, ベクトル表示をしている。この図か ら塩水循環流が形成されていることが認められ，右方水域から侵入した塩水は始め水平方向に流動 し，淡水との混合により希釈され，その結果密度が減少し上方に流向を転ずる。その後溶解塩分は淡 水流により外部塩水域まで流送され循環流が形成される。

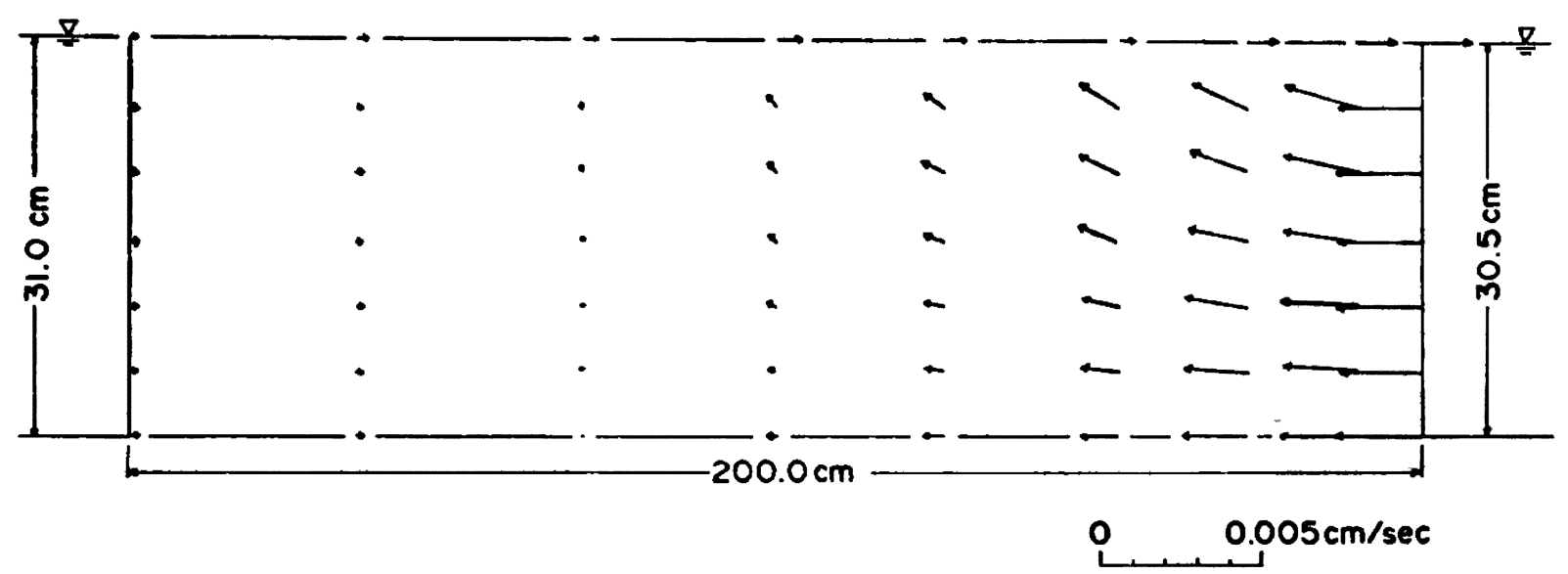

Ftg-13 Steady-State Velocity Distribution.

Fig-14は $D_{x}=0.20 \mathrm{~cm}^{2} / \mathrm{sec}, D_{y}=0.02 \mathrm{~cm}^{2} / \mathrm{sec}$ とした場合の 0.5 等濃度線の経時变化を示す。 初期条件は帯水層全域の塩分濃度を零に直く。定常解析と比較すると分散係数が一桁大さいため, 等濃度線間隔が㹟く, 0.5 等濃度線の侵入範囲は Fig-12 に比べて小さくなる。

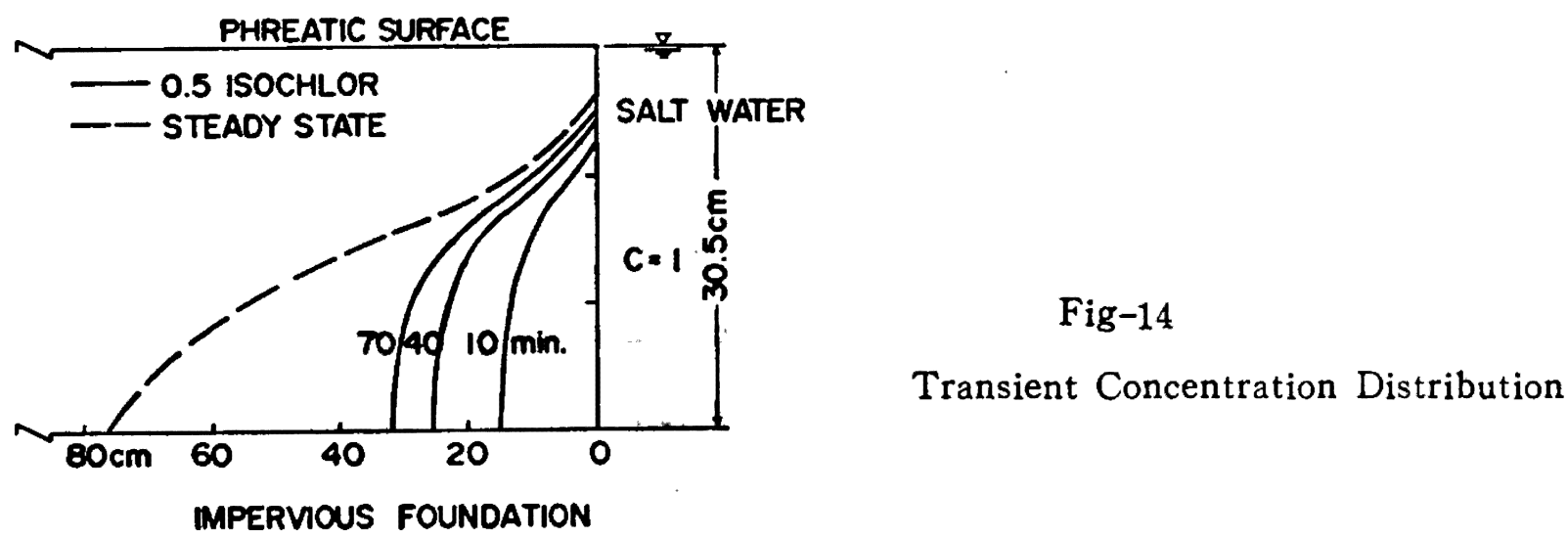

\section{6 結 論}

重味付残差法を用いて塩水侵入現象を非混合及び混合密度流と異った見地から解析を行い，解析手 法の適用性を調べた。

得られた結果を要約すると次の通りである。

（i ）本解析手法は, 非混合塩淡水密度流の内部境界面形状, 塩水侵入量及び淡水流出量に関して ，不王，被圧帯水層を問わず精度良く推定が行える。

（i i）塩水が静止状態にある場合たけでなく，塩，淡水が共に流動している同時密度流の解析が行 
え，また準一様流仮定が成立しない流動にも適用でき汎用性がある。

（iii）混合塩淡水密度流に関しては，分散係数の決定に不明確さがあるが，現在この問題に対する 解析法が確立されていないため，濃度変化の予測には有効な解析手法であると思われる。

最後に, 本研究を行うにあたり, 終始御指導を賜わった室商工業大学, 近藤俶郎教授, 山口久之助 教授に心から感謝致します。

\section{参考文 献}

尾島 勝 (1977)：揚水による塩水化現象の变化に関する解析, 第24回海岸工学講演会論文集, $553 \sim 557$ 。

嶋 裕之（1977）：地下水（密度流的諸問題），1971年水工学に関する夏期研修会講義集。 コーパー，コウアウト，ヘンリー，グロバー〔山ロ久之助訳〕（1967）臨海域の帯水層内における 海水，地下水と井戸とポンプ， $9-12 ， 2 \sim 14$.

Bear, J (1972) : Dynamics of Fluids in Porous Media, American Elsevier, 606 609.

Conner, J. J., C. A. Brebbia (1976) : Finite Elment Techniques for Fluid Flow, Newnes ButteIworths, $7 \sim 18$.

Pinder, G.F., W. G. Gray (1977) : Finite Element Simulation in Surface and Subsurface Hydrology, Academic Press, 163 183.

Rumer, R. R., D.R.F. Harleman (1963) : Intruded Salt-Water Wedge in Porous Media, Proc. of ASCE, Vol. 89, HY6, 193 220 .

Saffman, P.G. (1960) : Dispersion due to Molecular Diffusion and Macroscopic Mixing in Flow through a Network of Capillaries, Jour. Fluid Mech. 2-7, 194 208.

記号表

A：係数マトリックス（25式，30式，57式）

B : 係数マトリックス（25式，59式）

d：Hele-Shaw モデルに括ける通水部平行板間隔 [L]

C : 質量濃度 (無次元)

$\overline{\mathrm{C}}$ ： 質量濃度の近似解

$\mathrm{C}_{S}$ ： 最大の塩分質量濃度 $\left[N L^{-3}\right]$

D： 係数マトリックス（59式）

$D$ ：分散係数 $\left[L^{-2} T^{-1}\right]$

$D x$ : 横方向分散係数 $\left[L^{-2} T^{-1}\right]$

$D y ：$ 縦方向分散係数 $\left[L^{-2} T^{-1}\right]$

$\mathrm{E}$ : 俰数 (19式)

$\mathrm{e}$ : レオロジー定数

F： 解ベクトル（25式，30式，57式）

G：解ベクトル（59式）

$g$ : 重力加速度 [LT $\left.{ }^{-2}\right]$ 
$\mathrm{H}$ ：水頭 [L]

$\mathrm{h}_{1}$ ：是体内に打惊淡水深 [L]

$\mathrm{h}_{10}$ ：塩水域に流出する淡水深 [L]

$\mathrm{h}_{\mathbf{2}}$ ：堤体内に拈ける塩水深〔L]

$\mathrm{h}_{20}$ ：淡水域に流出する塩水深〔L]

$\mathrm{h}_{f}$ ：淡水域に括ける淡水深 [L]

hs：塩水域に括ける塩水深 [L]

$\mathrm{hs}_{0}$ ：淡水域に打ける塩水深 [L]

$\mathrm{i}$ : 流体種類, $\mathrm{i}=1$ 淡水, $\mathrm{i}=2$ 塩水諸元

$\mathrm{K}$ ：透水係数 $\left[L T^{-1}\right]$

$\mathrm{K} x$ ：水平方向の透水係数 $\left[L T^{-1}\right]$

$\mathrm{K} y$ ： 鉛直方向の透水係数 $\left[L T^{-1}\right]$

$\mathrm{k}$ ：固有透過度 [ $\left.\mathrm{L}^{2}\right]$

$\mathrm{L} i$ ：分演算子

$\mathrm{N} i ：$ 線形補間関数 (22式)

$\mathrm{n} e$ ： 有効空隙率 (0.30)

$\mathrm{n} ：$ 垷界飞立てた外向法線

$\mathrm{p}$ ： 压力 $\left[M L^{-1} T^{-2}\right]$

$\mathrm{q}^{\prime}$ ： Darcy 法則似よる浸透流速 [ $\left.\mathrm{LT}^{-1}\right]$

qo：単位時間, 単位面積当りの揚水量 $\left[\mathrm{T}^{-1}\right]$

$q$ is： 内部境界面飞沿与浸透流速 [ $\left[\mathrm{LT}^{-1}\right]$

$q n$ ：境界を横切る単位長さ当りの流速 [LT $\left.{ }^{-1}\right]$

$\mathrm{R}$ ： 解析領域

$S ：$ 比貯留量 $\left[\mathrm{L}^{-1}\right]$

$t ：$ 時刻 [T]

$\Delta t:$ 時間刻及 $[\mathrm{T}]$

$u_{m}$ : Hele-shaw モデルにおける平均流速 $\left[L T^{-1}\right]$

$u_{i}$ ：水平方向実流速成分 $\left[L T^{-1}\right]$

$\mathrm{V} i \mathrm{i}$ 実流速 $\left[L T^{-1}\right]$

$V_{m}$ ：境界を横切る単位長さ当りの質量流速 $\left[M L^{-2} T^{-1}\right]$

$v i ：$ 鉛直方向実流速成分 $\left[L T^{-1}\right]$

$\mathbf{X}$ ：解ベクトル（57式）

$\gamma_{i}$ ：流体の単位重量 $\left[M L^{-2} T^{-2}\right]$

$\epsilon_{i}$ : 残差

$\eta$ ：自然座標系の変数

$\theta$ : 内部境界面と水平軸との交角

$\mu_{i}:$ 粘性係数 $\left[M L^{-1} T^{-1}\right]$

$\xi ：$ 自然座標系の変数

$\rho:$ 密度 $\left[M L^{-3}\right]$ 
$\rho_{8}$ ：塩分の質量濃度 $\left[M L^{-3}\right]$

$\tau$ ：妿断応力 $\left[M L^{1} T^{-2}\right]$

（受付：1979年月 6 月 4 日，受理：1980年 1 月10日）

\section{正 誤 表}

第21巻第 3 号の下津氏他の論文「広域水収支に打ける地下水流動量の算定 阿蘇火山西簏部を 例として」中で下表のと拉りです。

\begin{tabular}{llll} 
頁 & 行 & \multicolumn{1}{c}{ 誤 } & 正 \\
17 & 13 & 標本平均 $x$ & 標本平均 $\bar{x}$ \\
17 & 14 & $t=\bar{x}-\mu / s / \sqrt{n-1}$ & $t=(\bar{x}-\mu) / s / \sqrt{n-1}$
\end{tabular}

第21巻第 3 号の開発一郎氏の論文「定常降雨中および降雨後の不飽和砂層中の鉛直水分移動」 中で下表のとおりです。

\begin{tabular}{|c|c|c|c|}
\hline 頁 & 行 & 誤 & 正 \\
\hline 21 & 表題 & aeter & after \\
\hline " & Abstract 中 13 & movemnt & movement \\
\hline " & Abstract 中 18 & paralle & parallel \\
\hline 22 & 36 & $\operatorname{chn}$ & chu \\
\hline 26 & Fig-4の説明文中 8 & saod & sand \\
\hline 30 & Fig-9の説明文中 3 & aod & and \\
\hline$"$ & 10 & （口印は）， & （印）は。 \\
\hline 32 & 29 & (drairage) & (drainage) \\
\hline 33 & Fig-10の説明文中 1 & $\mathrm{~g}$ adients & gradients \\
\hline " & Fig-10の説明文中 2 & $g$ adients & gradients \\
\hline 34 & 19 & 粗砂では細 & 粗砂では 1 細 \\
\hline 35 & 15 & 求めること & 求めると \\
\hline " & 29 & ( (1966) & (1966) \\
\hline " & 37 & 浸透 & 浸透(2) \\
\hline 36 & 18 & Tranactions & Transactions \\
\hline
\end{tabular}

